\title{
Characteristics of "Success" among Academic Librarians
}

John N. Olsgaard

This study examines selected characteristics of U.S. academic librarians listed in Who's Who in Library and Information Services. Through use of a systematic sample of entries, a composite profile of attributes of successful academic librarians was delineated. Among the results that were tabulated in this study were: men had a greater chance of being deemed successful in the profession; approximately a third of the academic entries had advanced degrees in addition to the M.L.S.; and successful academic librarians tended to work in ARL-member institutions. A discussion of the problem of determining "success" for academic librarians and recommendations for further research are also given.

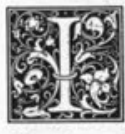

$\mathrm{n}$ his book about the Mercury space program, writer Tom Wolfe attempted to define the factors that led to the selection of the successful astronauts. Unable to adequately describe these factors, he decided that the successful astronauts had "the right stuff"; they had whatever it took to succeed. ${ }^{1}$ In a similar way, one of the more difficult problems in the field of academic librarianship is the measurement of what constitutes "success" in the profession. What makes the successful librarian different from the unsuccessful librarian? What may initially seem to be merely a speculative question becomes more important when one is serving on a tenure committee or completing a performance evaluation. It is at the time that one is evaluating the success of another individual that the question becomes especially pragmatic. The purpose of this study is to conduct a preliminary investigation into the characteristics of success among academic librarians.

Unlike the business community, where success can be measured in terms of wealth, the nonprofit sector, including librarianship, must develop other measures of achievement. Logically there are two methods of determining whether a li- brarian has been successful. The first is to set up a theoretical model of what constitutes success, and then to compare individuals against that ideal state. The second method of determining success is to gather together a group of those individuals thought to be successful and determine what attributes they have in common. This study will share the characteristics of both methods.

In 1982 the American Library Association published a biographical directory entitled Who's Who in Library and Information Services, which listed some twelve thousand of the more successful contributors to the field of library and information science in the United States and Canada. Success was judged by the editors of Who's Who on the basis of a comparison of individuals against a theoretical model composed of the following guidelines:

1. Evidence of active participation in professional, educational, or service organizations.

2. A record of activity in support of libraries and information services.

3. Substantial experience as a practitioner or educator.

4. Contributions to the professional literature.

5. Receipt of awards or honors from 
professional or educational organizations. ${ }^{2}$

Assuming that Who's Who does provide the best available estimate of what constitutes success in the profession, it can be further presumed that certain attributes of those included in the listing can be measured and calculated. Who's Who was used in much this same manner to examine the characteristics of ARL directors in an article by Ronald Dale Karr. ${ }^{3}$ This study will measure selected personal characteristics of U.S. academic librarians listed in Who's Who in all types of academic institutions and job positions. A product of this examination of the "successful" is to explore the possible direction the profession is moving in several educational and employment areas.

\section{METHOD}

Data for this study were collected by using a systematic sample of the entries in Who's Who (in this case $k=31$ ). The sample size needed to validate a bound on the error of .05 was delineated by use of a proportional allocation model where, through use of a pre-sample, the proportion of academic listings to nonacademic listings was estimated at .4 to .6 , respectively (see appendix A). The intent of the above formulation was to draw a valid sample of a subset (i.e., academic librarians) from the population (i.e., all listings in Who's Who) within statistically controlled bounds. In this case the sample size needed to validate the survey was 373. The number of entries collected totaled 382. The general composition of the sample is given in table 1 . The following rules were implemented to standardize entries and to make the results compatible with previous research. ${ }^{4}$

1. To determine the sex of an entry, an analysis of first names was undertaken in conjunction with the following rules: (a) first names that could be of either gender or that were not recognizable as being attributable to either gender were listed as indeterminable; and (b) first names of entries represented only by initials were listed as indeterminable.

2. Age was calculated using 1980 as a base year.
3. The data entry for a college or for a university was taken directly from the institutional name.

4. In the context of this study, the job designation of administrator includes the job titles of director, dean, and associate or assistant dean of an academic library. Administrative titles of departmental libraries were listed as departmental job positions.

TABLE 1

COMPOSITION OF WHO'S WHO SAMPLE

\begin{tabular}{lrr}
\hline \hline Type & \multicolumn{1}{c}{$N=$} \\
\hline Academic & 148 & \multicolumn{1}{c}{$\%$} \\
Special & 87 & 23 \\
Public & 49 & 13 \\
School & 24 & 6 \\
Library school faculty & 17 & 4 \\
Retired & 7 & 2 \\
Non-U.S. & 23 & 6 \\
Other & $\underline{27}$ & $\underline{7}$ \\
Total & 382 & 100 \\
\hline
\end{tabular}

5. Geographic location was entered by grouping states into the following regions: (a) Northeast-Connecticut, Delaware, District of Columbia, Maine, Maryland, Massachusetts, New Hampshire, New Jersey, New York, Pennsylvania, Rhode Island, Vermont; (b) SoutheastAlabama, Florida, Georgia, Kentucky, North Carolina, South Carolina, Tennessee, Virginia, West Virginia; (c) Midwest-Illinois, Indiana, Iowa, Kansas, Michigan, Minnesota, Missouri, Nebraska, North Dakota, Ohio, South Dakota, Wisconsin; (d) Southwest-Arizona, Arkansas, Louisiana, Mississippi, New Mexico, Oklahoma, Texas; (e) West-Alaska, California, Colorado, Hawaii, Idaho, Montana, Nevada, Oregon, Utah, Washington, Wyoming.

6. For purposes of this study, a publication was defined as a titled print article or monograph. Editorships and nonprint projects were not included.

The data collected are presented within four general headings: I. Demographic Characteristics; II. Educational Degree Obtainment Characteristics; III. Employment Characteristics; and IV. Publication Characteristics. 
TABLE 2

GENDER OF ACADEMIC LISTINGS BY REGION

\begin{tabular}{lccccc}
\hline \hline Region & $\begin{array}{c}\text { Women } \\
\text { (Percent) }\end{array}$ & $\begin{array}{c}\text { Men } \\
\text { (Percent) }\end{array}$ & $N=$ & $d=^{*}$ & $N-d=$ \\
\hline Northeast & 43.2 & 56.8 & 40 & 3 & 37 \\
Southeast & 52.2 & 47.8 & 24 & 1 & 23 \\
Midwest & 66.7 & 33.3 & 30 & 0 & 30 \\
Southwest & 46.2 & 53.8 & 14 & 1 & 13 \\
West & 44.2 & 55.6 & 40 & 4 & 36 \\
Composite average & 50.4 & 49.6 & 148 & 9 & 139 \\
Population average & 61.5 & $38.5 t$ & & & \\
\hline
\end{tabular}

* $d$ is the number of entries for which data could not be determined.

tRepresents the percentage of all U.S. academic librarians. Association of College and Research Libraries, Salary Structures in Higher Education for the Academic Year 1975-1976 (Chicago: American Library Assn., 1976), p.6-12.

\section{DEMOGRAPHIC CHARACTERISTICS OF ACADEMIC ENTRIES}

The analysis of demographic characteristics of the academic library listings from Who's Who followed a three-level design. The first level of consideration was to determine the proportion of academic entries that were female or male (see table 2). Although the sample national proportions were roughly of equivalent size, the percentage of female listings was ten percentage points below their representative national proportion of the population. However, it should be noted that the difference between the proportions given from the Who's Who listings and the proportions of the population was only marginally statistically significant (chi-sq. = $2.86,0.10 \geq 2.71$, d.f. $=1$ ). That is, one can be 90 percent sure that the difference between the sample proportion and the population proportion was not caused by a chance distribution.

The second level of consideration was to determine the geographic location of academic listings in Who's Who. The results of this examination are presented in table 3. Every region of the U.S. was slightly underrepresented in comparison to their proportion of the population, with the exception of the West region. For example, while 27 percent of the sampled listings in Who's Who resided in the Northeast, 31.3 percent of all academic librarians in the U.S. are in the Northeast region. This small difference between the geographic location of the Who's Who listings and the geographic location of the population of
TABLE 3

GEOGRAPHIC DISTRIBUTION OF ACADEMIC ENTRIES

\begin{tabular}{|c|c|c|c|}
\hline Region & $N=$ & $\begin{array}{l}\text { Who's Who } \\
\text { Listings } \\
\text { (in Percent) }\end{array}$ & $\begin{array}{l}\text { Population } \\
\text { Regional } \\
\text { Average* } \\
\text { (in Percent) }\end{array}$ \\
\hline Northeast & 40 & 27.0 & 31.3 \\
\hline Southeast & 24 & 16.2 & 17.3 \\
\hline Midwest & 30 & 20.3 & 24.7 \\
\hline Southwest & 14 & 9.5 & 11.1 \\
\hline West & 40 & 27.0 & 15.6 \\
\hline Total & 148 & 100.0 & 100.0 \\
\hline
\end{tabular}

*Represents percentages of all U.S. academic librarians. Data derived from U.S. Department of Health, Education and Welfare. National Center for Education Statistics, Library Statistics of Colleges and Universities, Fall 1975: Institutional Data (Washington, D.C.: Govt. Print. Off., 1977), p.221-78.

academic librarians was statistically insignificant (chi-sq. $=5.89,0.05 \geq 9.49$, d.f. $=4$ ). For general purposes this would indicate that the Who's Who listings of academic librarians, and by implication the sample drawn from it, are representative of the general population of academic librarians in the case of geographic location.

The third level of analysis examined the age of academic listings in Who's Who. The average age of all academic listings was $43.9(N=131)$. However, the average age for men was $45.6(N=69)$ and for women was $42.0(N=62)$. A histogram of the class frequency distributions in age is given in figure 1 . This analysis demonstrates that a high proportion of the women academic librarians were in their thirties ( 48 percent), whereas only 28 percent of the men were in the same class frequency. Although the above distribution 


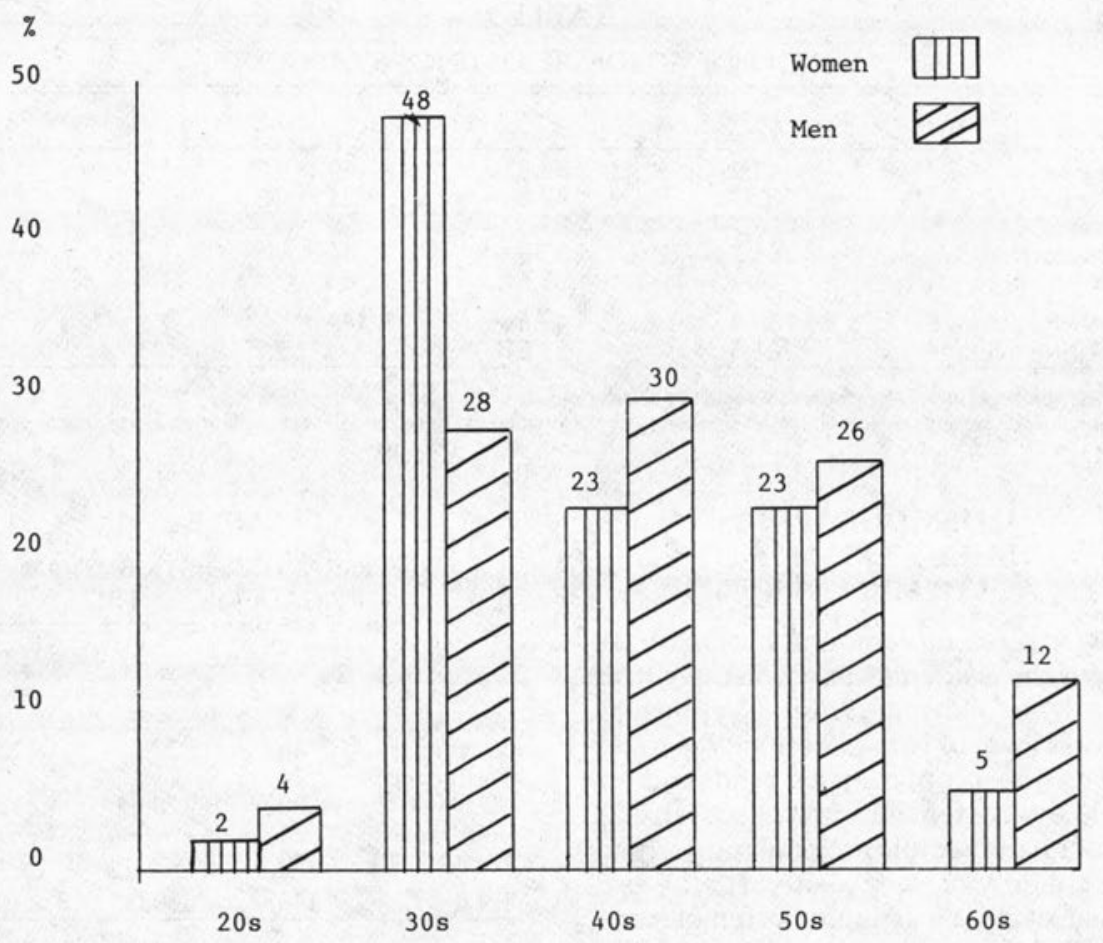

FIGURE 1

Frequency Histogram of Academic Entries by Age and Gender

may be arithmetically important, it does not demonstrate strictly statistically significant results (chi-sq. $=7.29,0.20 \geq$ 5.99, d.f. $=4$ ).

\section{EDUCATIONAL DEGREE OBTAINMENT OF ACADEMIC LISTINGS}

Several sections of analysis were used to quantitatively describe the educational degree obtainment of the academic listings in Who's Who. All sample entries had at least a bachelor's degree. The data in table 4 reflect the percentage of the sampled academic librarians that have been granted various professional and graduate degrees.

At the bachelor's degree level of educational obtainment, an analysis was conducted of the subject majors given for academic listings (see table 5). The vast majority (nearly two-thirds) of all the academic listings had subject majors in the humanities. The most popular undergrad- uate subjects were in the fields of English and history, composing 25 percent and 21 percent of all listings, respectively. The percentages between men and women academic librarians were nearly identical in most broad categories of majors with the exception of the sciences, where men held

TABLE 4

\section{EDUCATIONAL DEGREE OBTAINMENT OF ACADEMIC ENTRIES}

\begin{tabular}{|c|c|c|}
\hline Degree Type & $N=$ & $\%={ }^{*}$ \\
\hline $\begin{array}{l}\text { Professional } \\
\text { B.L.S. only } \\
\text { M.L.S. }\end{array}$ & $\begin{array}{r}7 \\
136\end{array}$ & $\begin{array}{r}4.7 \\
91.9\end{array}$ \\
\hline $\begin{array}{l}\text { Neither B.L.S. } \\
\text { nor M.L.S. }\end{array}$ & 5 & 3.4 \\
\hline $\begin{array}{l}\text { Advanced } \\
\text { M.L.S. \& } 2 \mathrm{~d} \text { Master's } \\
\text { M.L.S. \& Doctoratet } \\
\text { M.L.S. \& Doctorate in }\end{array}$ & $\begin{array}{l}47 \\
10\end{array}$ & $\begin{array}{r}34.6 \\
7.4\end{array}$ \\
\hline $\begin{array}{l}\text { Library \& Info. Sci- } \\
\text { ence }\end{array}$ & 2 & 1.5 \\
\hline
\end{tabular}

*As a percentage of all academic entries.

tIncludes Ph.D., Ed.D., D.L.S., and D.A. 
TABLE 5

BACHELOR'S DEGREE MAJOR SUBJECT AREA FOR ACADEMIC ENTRIES

\begin{tabular}{|c|c|c|c|c|c|c|}
\hline \multirow[b]{2}{*}{ Category } & \multicolumn{2}{|c|}{ Women } & \multicolumn{2}{|c|}{ Men } & \multicolumn{2}{|c|}{ All Entries } \\
\hline & $N=$ & $\%=$ & $N=$ & $\%=$ & $N=$ & $\%=$ \\
\hline Humanities* & 47 & 68.1 & 42 & 62.7 & 89 & 65.4 \\
\hline Social Sciencest & 8 & 11.6 & 8 & 11.9 & 16 & 11.8 \\
\hline Applied Sciences $\ddagger$ & 13 & 18.8 & 11 & 16.4 & 24 & 17.6 \\
\hline Sciences§ & 1 & 1.4 & 6 & 9.0 & 7 & 5.1 \\
\hline Total & 69 & 99.9 & 67 & 100.0 & 136 & 99.9 \\
\hline
\end{tabular}

The number entries for which data could not be determined $=12$.

"Humanities includes the subjects: history, English, languages, music, philosophy, art, religion.

tSocial sciences includes the subjects: sociology, economics, political science, government, anthropology, communications, psychology.

$\ddagger$ Applied sciences includes the subjects: education, mathematics, geography, journalism, business, geology, forestry, health sciences (e.g., nursing).

§Sciences includes the subjects: biology, physics, zoology, chemistry.

a 9 percent to 1.4 percent superiority (chisq. $=3.99,0.05 \geq 7.82$, d.f. $=3$ ).

The second educational degree obtainment level analysis was conducted for those academic librarians that had received a master's degree in library science. As no surprise, the M.L.S. is the professional degree of preference among academic librarians; 92 percent have been awarded an M.L.S. versus 5 percent that have a bachelor's degree in library science, or the 3 percent that have neither the M.L.S. nor the B.L.S. On first examination, one could be led to infer that the level of M.L.S. obtainment among the entries in Who's Who (i.e., 92 percent) was actually less than the M.L.S. obtainment level for the general population reported by Michael D. Cooper in 1976 (i.e., 95 percent). ${ }^{5}$ The difference of 3 percent was probably due to sampling error, rather than actual differences between the two groups (chisq. $=0.71,0.05 \geq 3.84$, d.f. $=1$ ). However, it should also be noted that there is no evidence that the rate of M.L.S. obtainment among the academic entries in Who's Who is any higher than it is in the normal population.

Those academic librarians sampled that do have an M.L.S. are alumni of forty-two different library schools. An interesting sidelight to this examination is a frequency distribution ranking of library schools that was constructed of these listings and compared to a perception ranking of library schools by library administrators conducted by Herbert S. White in 1981 (see table 6). ${ }^{6}$ The top fifteen ranked schools generated from the listings in this study represent the granting institutions of the M.L.S. to 64 percent of all the academic librarians sampled from Who's Who. Although the rank order of the library schools between the White study and this study's results are quite different, there is still a 53 percent (nine of seventeen) agreement rate between the composition of the lists.

The next educational degree obtainment level surveyed was for other graduate degrees in addition to the M.L.S.

Approximately one in three of the academic librarians listed in Who's Who had a master's degree in addition to an M.L.S. (34.6 percent). Of the group that had a second master's degree, 61 percent were men and 39 percent were women; a difference that was statistically significant at the 0.10 level (chi-sq. $=3.73,0.10 \geq 2.71$, d.f. $=$ 1).

The subject majors of the non-M.L.S. master's degrees followed a pattern quite similar to the data collected for bachelor's degrees. As with bachelor's degree data, nearly two-thirds of the non-M.L.S. master's degrees were in the humanities (see table 7). Among those that had received a master's degree in addition to the M.L.S., women held a small proportional superiority in both the humanities and the social sciences, while men held the proportional advantage in the applied sciences and the sciences. These subject differences were not statistically significant (chi-sq. = $2.66,0.05 \geq 7.82$, d.f. $=3$ ).

Of considerable interest to many in the 
TABLE 6

FREQUENCY DISTRIBUTION OF LIBRARY SCHOOLS ATTENDED BY ACADEMIC ENTRIES

\begin{tabular}{|c|c|}
\hline Who's Who Entries & White's Perception Studyt \\
\hline $\begin{array}{l}\text { 1. Columbia }(13)^{\star} \\
\text { 2. Michigan }(11)^{\star} \\
\text { 3. Ilinois }(7)^{\star} \\
\text { 4. Indiana }(6)^{\star} \\
\text { Washington }(6)^{\star} \\
\text { 6. Catholic (5) } \\
\text { Denver (5) } \\
\text { Peabody (5) } \\
\text { Simmons (5) } \\
\text { 10. California, Berkeley }(4)^{\star} \\
\text { Florida State (4) } \\
\text { North Carolina }(4)^{\star} \\
\text { Oklahoma (4) } \\
\text { Pittsburgh (4) } \\
\text { Syracuse (4) } \\
\text { USC (4) }\end{array}$ & $\begin{array}{l}\text { 1. Illinois (44) } \\
\text { 2. Michigan (41) } \\
\text { 3. California, Berkeley (38) } \\
\text { Chicago (38) } \\
\text { 5. UCLA (37) } \\
\text { 6. Columbia (32) } \\
\text { 7. Indiana (31) } \\
\text { 8. North Carolina (29) } \\
\text { 9. Pittsburgh (24) } \\
\text { 10. Rutgers (19) } \\
\text { 11. Simmons (15) } \\
\text { 12. Drexel (9) } \\
\text { 13. Washington (8) } \\
\text { Wis., Madison (8) } \\
\text { 15. British Col. (6) } \\
\text { Case Western (6) } \\
\text { Texas, Austin (6) }\end{array}$ \\
\hline $\begin{array}{l}53 \text { additional entries distributed among } 26 \\
\text { other schools. }\end{array}$ & $\begin{array}{l}39 \text { additional responses distributed among } 19 \\
\text { other schools. }\end{array}$ \\
\hline
\end{tabular}

"Matches between the two lists.

tSource: Herbert S. White, "Perceptions by Educators and Administrators of the Ranking of Library School Programs," College \& Research Libraries 42:198 (May 1981).

TABLE 7

NON-M.L.S. MASTER'S DEGREE MAJOR SUBJECT AREA FOR ACADEMIC ENTRIES

\begin{tabular}{|c|c|c|c|c|c|c|}
\hline \multirow[b]{2}{*}{ Category } & \multicolumn{2}{|c|}{ Women } & \multicolumn{2}{|c|}{ Men } & \multicolumn{2}{|c|}{ All Entries } \\
\hline & $N=$ & $\%=$ & $N=$ & $\%=$ & $N=$ & $\%=$ \\
\hline Humanities & 12 & 70.6 & 17 & 63.0 & 29 & 65.9 \\
\hline Social Sciences & 2 & 11.8 & 1 & 3.7 & 3 & 6.8 \\
\hline Applied Sciences & 3 & 17.6 & 7 & 25.9 & 10 & 22.7 \\
\hline Sciences & 0 & - & 2 & 7.4 & 2 & 4.5 \\
\hline Total & 17 & 100 & 27 & 100 & 44 & 99.9 \\
\hline
\end{tabular}

The number of entries for which data could not be determined $=3$.

profession is the extent to which the doctorate is becoming a prevalent requirement in job listings for administrative positions in academic libraries. Olsgaard and Olsgaard have reported that nearly 40 percent of the job listings for directors of university libraries preferred a doctorate. ${ }^{7}$ Of those academic librarians sampled in Who's Who that had an M.L.S., only 7.4 percent also had earned a doctorate (i.e., Ph.D., Ed.D., D.L.S., or D.A.) in any field, and only 1.5 percent had doctorates in library and information science. On a more comparable level, 13.6 percent of the sampled administrators in Who's Who had a doctorate in some field. The difference between the obtainment level of the doc- torate among the sampled administrators and the level requested in job listings was statistically significant (chi-sq. $=6.41$, $0.05 \geq 3.84$, d.f. $=1$ ).

The last level of consideration dealt with the average age that degrees were obtained at various educational levels (see table 8 ). The average age of men and women was quite similar at both the bachelor's degree level and at the M.L.S. degree level. However, an interesting phenomenon does occur for those listings that have both an M.L.S. and a second master's degree. While women academic librarians who had both degrees received a non-M.L.S. master's degree an average of approximately two years after receiving 
TABLE 8

MEAN AVERAGE AGE OF EDUCATIONAL DEGREE OBTAINMENT FOR ACADEMIC ENTRIES

\begin{tabular}{lcccccr}
\hline \hline Degree & Women & Men & All Entries & $N=$ & $d==^{\star}$ & $N-d=$ \\
\hline Bachelor's & 23.6 & 23.3 & 23.4 & 148 & 17 & 131 \\
M.L.S. & 30.0 & 29.4 & 29.7 & 148 & 27 & 121 \\
M.L.S.+ 2d Master's & 31.8 & 28.3 & 29.5 & 47 & 7 & 40 \\
\hline
\end{tabular}

* $d$ is the number of entries for which data could not be determined.

an M.L.S., men academic librarians who had both degrees received their nonM.L.S. master's degree an average of one year before the M.L.S. However, the statistical significance of this difference is questionable (chi-sq. $=0.10,0.05 \geq 5.99$, d.f. $=2$ ).

\section{EMPLOYMENT CHARACTERISTICS OF ACADEMIC ENTRIES}

The analysis of the employment characteristics of the academic librarians listed in Who's Who will follow a two-level design. The first level of consideration was the distribution of academic librarians by the type of institution in which they were employed (see table 9). The highest distribution frequency was for academic librarians employed in ARL-member U.S. academic libraries. ${ }^{8}$ Nearly 46 percent of all the listings for academic librarians were employed in ARL institutions. The lowest class frequency was for academic librarians employed in two-year colleges with 7.4 percent. A frequency histogram of the distribution of entries by institution is given in figure 2.

The second level of analysis of employment characteristics examined the type of job held by the academic librarians listed in Who's Who. The results, as given in table 10 , are that nearly a third ( 31.7 percent) of all the academic listings are in an administrative position. The next most frequent position was for the categories of reference librarians or departmental librarians, both having approximately 18 percent of all the academic listings. It is interesting to note that while 42 percent of the entries for men were in administrative positions, the highest frequency for any job category among women was for the position of reference librarian ( 24.3 percent). The difference between the number of men in administrative positions and the number of women in administrative positions is statistically significant (chi-sq. $=5.90,0.05$ $\geq 3.84$, d.f. $=1$ ).

\section{PUBLICATION ACTIVITY OF ACADEMIC ENTRIES}

The last area examined was the publication activity of the academic listings in Who's Who. The analysis of this section again followed a two-level design and is presented in table 11. The first level of analysis examines the publication activity of men and women academic librarians. Although the overall rate for all entries was an average of 1.5 publications per entry, the rate for men academic librarians was nearly twice that of women academic librarians (2.0 to 1.1 , respectively).

The second level of publication analysis examined the rate of publication by the

TABLE 9

EMPLOYING ACADEMIC INSTITUTION

\begin{tabular}{|c|c|c|c|c|c|c|c|}
\hline \multirow[b]{2}{*}{ Type } & \multicolumn{2}{|c|}{ Women } & \multicolumn{2}{|c|}{ Men } & \multirow[b]{2}{*}{$d={ }^{*}$} & \multicolumn{2}{|c|}{ All Entries } \\
\hline & $N=$ & $\%=$ & $N=$ & $\%=$ & & $N=$ & $\%=$ \\
\hline ARL & 30 & 45.5 & 36 & 54.5 & 2 & 68 & 45.9 \\
\hline Non-ARL University & 21 & 55.3 & 17 & 44.7 & 4 & 42 & 28.4 \\
\hline Four-Year College & 11 & 44.0 & 14 & 56.0 & 2 & 27 & 18.2 \\
\hline Two-Year College & 8 & 80.0 & 2 & 20.0 & 1 & 11 & 7.4 \\
\hline Total & 70 & & 69 & & 9 & 148 & 99.9 \\
\hline
\end{tabular}

* $d$ is the number of entries for which gender data could not be determined. 
50

40

0

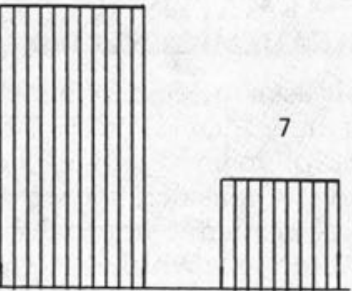

ARL

$\begin{array}{ll}\text { Four } & \text { Two } \\ \text { Year } & \text { Year } \\ \text { College } & \text { College }\end{array}$

FIGURE 2

Frequency Histogram by Institutional Type

type of academic institution in which the entries were employed. It was found that those employed in ARL institutions had the highest publication rate among the various types of academic institutions. However, the size of the institution does not necessarily accurately predict the publication activity of the entries; for example, those employed in non-ARL university libraries had a slightly smaller publication rate than those employed in two-year colleges.

TABLE 10

JOB POSITIONS OF ACADEMIC ENTRIES

\begin{tabular}{lrrrrrr}
\hline \hline \multirow{2}{*}{ Type } & $N=$ Women $^{2}$ & \multicolumn{2}{c}{ Men } & \multicolumn{2}{c}{ All Entries } \\
\hline Administration & 15 & 21.4 & 29 & 42.0 & 44 & 31.7 \\
Reference & 17 & 24.3 & 8 & 11.6 & 25 & 18.0 \\
Acquisitions/Collection & 3 & 4.3 & 4 & 5.8 & 7 & 5.0 \\
Health Sciences & 4 & 5.7 & 1 & 1.4 & 5 & 3.6 \\
Cataloging & 5 & 7.1 & 2 & 2.9 & 7 & 5.0 \\
Departmental & 12 & 17.1 & 15 & 21.7 & 27 & 19.4 \\
Bibliographer & 2 & 2.9 & 2 & 2.9 & 4 & 2.9 \\
Law & 5 & 7.1 & 3 & 4.3 & 8 & 5.8 \\
Other & 7 & 10.0 & $\underline{5}$ & $\underline{7.2}$ & $\underline{12}$ & $\frac{8.6}{100}$ \\
Total & 70 & 99.9 & 69 & 99.8 & 139 & 100 \\
\hline
\end{tabular}

"The number of entries for which data could not be determined $=9$. 
TABLE 11

MEAN AVERAGE PUBLICATION RATE FOR ACADEMIC ENTRIES

\begin{tabular}{lcc}
\hline \hline Category & $N=$ & $\begin{array}{c}\text { Mean } \\
\text { Rate }\end{array}$ \\
\hline Gender & 70 & 1.1 \\
Women & 69 & 2.0 \\
Men & & \\
Institution & 68 & 1.7 \\
ARL & 42 & 1.2 \\
Non-ARL University & 27 & 1.6 \\
Four-Year College & 11 & 1.3 \\
Two-Year College & 148 & 1.5 \\
All Entries & & \\
\hline
\end{tabular}

\section{DISCUSSION AND RECOMMENDATIONS FOR FURTHER RESEARCH}

Using the above analyses, and assuming that the entries portray a set of attributes accepted as describing the "successful" librarian, it is possible to draw a composite profile representing a majority of those academic librarians listed in Who's Who.

\section{Demographic Characteristics:}

1. Gender. Although there are approximately the same number of men and women academic librarians who are successful, there is a better chance to succeed if one is male.

2. Geographic location. A majority of successful librarians reside in the Northeast or West regions.

3. Age. The successful academic librarian is in his/her forties (the men being slightly older than the women).

II. Educational Degree Obtainment Characteristics:

1. The successful academic librarian has a bachelor's degree, preferably in the humanities.

2. The successful academic librarian has an M.L.S., preferably from a highly ranked school.

3. The successful academic librarian probably does not have an advanced degree in addition to the M.L.S., but a large number of his/her colleagues do have one in the humanities.

\section{Employment Characteristics:}

1. It is highly probable that the successful academic librarian will work in a large academic library rather than in a small institution.

2. The successful male academic librarian will probably be an administrator. The successful female academic librarian could be an administrator, but would more likely be a reference librarian.

IV. Publication Characteristics:

1. The successful academic librarian publishes in the professional literature, but does not publish very much.

The purpose of this study was to observe certain quantifiable characteristics of successful academic librarians, at least as judged by one set of standards for success. That is not to assert that these standards for success encompass an exclusive list, or that the characteristics of those judged to be successful are necessarily desirable. For example, while it is not necessarily desirable that most administrators are men, it is important to observe that most administrators are men.

It could also be claimed that most successful librarians demonstrate certain qualitative characteristics such as having a "pleasant personality." While such claims might be true, it would probably be impossible to describe those characteristics either in a study such as this, or when dealing with the legalities of a tenure hearing. What is needed is a set of measurable standards for success that would guide performance evaluation committees and library school educators. This future study would establish a theoretical model of success that would be acceptable to the majority of the profession. After all, the profession can hardly berate administrators for not demanding excellence, or educators for not teaching the "right stuff," if we don't know what constitutes the "right stuff."

\section{REFERENCES}

1. Tom Wolfe, The Right Stuff (New York: Farrar, 1979). 
2. Joel Lee, ed., Who's Who in Library and Information Services (Chicago: American Library Assn., 1982), p.ix.

3. Ronald Dale Karr, "Becoming a Library Director," Library Journal 108:343-46 (Feb. 15, 1983).

4. Martha C. Adamson and Gloria J. Zamora, "Publishing in Library Science Journals: A Test of the Olsgaard Profile," College \& Research Libraries 42:235-41 (May 1981); Bob Carmack and John N. Olsgaard, "Population Characteristics of Academic Librarians," College \& Research Libraries News 42:141-42 (May 1981).

5. Michael D. Cooper, "A Statistical Portrait of Librarians: What the Numbers Say," American Libraries 7:327-30 (June 1976).

6. Herbert S. White, "Perceptions by Educators and Administrators of the Ranking of Library School Programs," College \& Research Libraries 42:191-202 (May 1981).

7. John N. Olsgaard and Jane Kinch Olsgaard, "Post-MLS Educational Requirements for Academic Librarians," College \& Research Libraries 42:224-28 (May 1981).

8. U.S. academic institutions that were members of ARL were taken from Gordon Fretwell, comp., ARL Annual Salary Survey, 1979-1980 (Washington, D.C.: Association of Research Libraries, 1980).

\section{APPENDIX A: PROPORTIONAL ALLOCATION MODEL}

$$
\begin{aligned}
& n=\frac{N p q}{(N-1) D+p q} \\
& \text { where } \quad D=\frac{B^{2}}{4}
\end{aligned}
$$

\footnotetext{
$n=$ sample size

$N=$ population size

$p=$ estimate of the proportion that are academic librarians

$q=1-p$

$B=$ bound on the error of estimation; in this case .05
} 